\title{
探究水利工程管理确保水利工程安全
}

\author{
刘媛媛 \\ 静乐县水利局 \\ DOI:10.32629/hwr.v4i8.3244
}

\begin{abstract}
[摘 要] 在水利工程施工中, 安全一直是有关部门重点关注的问题,当前我国正处于快速发展阶段,并且 水利工程在社会发展中, 也起到了十分重要的作用,但是水利工程涉及的施工环节较多并且工程规模较 大, 这就导致在水利工程施工过程中, 经常会出现各种安全问题严重影响工程建设。因此, 为了保证水利 工程稳定建设, 并保证水利工程施工安全, 避免出现生产安全问题, 有关部门就加大了对水利工程管理的 力度,进而提高水利工程建设速度,保证施工人员生命财产安全,进一步推动了我国现代化发展进程。
\end{abstract}

[关键词] 水利工程; 建设管理; 工程安全; 实施策略

中图分类号: TV732 文献标识码: A

在科学技术不断发展过程中, 我国 人民群众的生活质量不断提高, 同时我 国水利工程项目也在高效的建设中, 为 我国带来了显著的经济效益, 可是随着 社会的发展, 水利工程施工却出现了不 同程度的问题, 使得水利工程质量受到 了严重影响。出现这些问题的主要原因 就是: 有关部门安全意识不足、缺乏系 统的安全管理规范等, 这些看似细微的 问题却导致了水利工程安全事故频发。 为了避免水利工程在施工中出现安全问 题, 并降低水利工程施工安全隐患, 根据 近段时间的总结, 整理出了如何通过水 利工程管理, 提高水利工程安全的一系 列措施, 希望可以为有关部门提供有效 帮助 ${ }^{[1]}$ 。

\section{1 水利工程施工安全管理的} 意义

在社会与经济发展过程中, 水利工 程是十分重要的发展设施, 并且我国也 在大力开展水利工程的建设, 从而进一 步提高我国经济效益推动我国稳定发 展。但是在实际施工过程中, 由于安全意 识不足, 缺乏系统的安全管理规范, 就使 得施工人员在工作过程中, 经常会出现 生产安全问题, 水利工程施工人员的生 命安全受到了威胁。为了保证水利工程 施工安全, 降低生产安全事故发生率, 有 关部门就针对工程管理方式进行了优化,
并着重关注水利工程安全管理。进而提 高水利工程施工安全, 保证施工人员生 命财产安全, 有效建立我国水利工程管 理措施, 以推动我国社会与经济发展, 为 群众的生活带来便利。

\section{2 水利工程施工安全管理中存 在的问题}

2.1 施工场地及人员统一管理难 度大

水利工程通常建立在大江大河之上, 这就导致水利工程建设项目较大, 一般 需要多个施工团队配合, 才能够完成水 利工程整体施工。就因为水利工程项目 较大, 就造成了在建设过程中施工场地 相对分散, 进而出现了由于施工场地相 隔较远无法统一管理的问题。与此同时, 在水利工程施工过程中, 所涉及的施工 人员众多并且施工人员的工作种类不同, 这一问题也影响到了工程管理的效率, 所以在长时间施工过程中就会出现纰漏, 从而导致生产安全事故频频发生。

2.2施工企业管理不到位

施工企业在对工程进行管理时, 企 业内部没有制定规范的管理方式, 为了 快速推进水利工程项目建设, 在规划过 程中, 就会忽视安全管理的问题, 一味的 追求施工速度, 提高企业经济效益降低 施工成本, 导致水利工程出现安全隐患。 有些施工企业为了降低施工成本, 还会
聘请大量专业能力不足的农民工, 并且 在施工场地还没有明显的安全生产标 志, 最终导致安全管理人员安全意识松 解, 例如物料堆放不合理造成物料堆坞 塌。部分施工人员更是将方便施工贯彻 到了每一个细节, 机械设备在水利工程 中经常出现, 部分施工人员为了方便工 作, 就会让机械设备长期处于空转状 态。这就导致机械设备在长时间运行过 程中, 出现了严重老化的问题, 对施工 人员生命安全造成了威胁, 进而影响水 利工程施工进度, 同时也对施工质量造 成了威胁 ${ }^{[2]}$ 。

\section{3安全人员管理意识淡薄}

因为水利工程项目较大, 并且需要 很长时间才能完成建设, 这就导致安全 人员在管理过程中, 经常会出现各种管 理漏洞, 严重影响到了水利工程施工安 全。就拿水利工程中的电力供给设备管 理来说, 很多安全管理人员在工作中, 就 总是会出现疏于检查的问题。这就导致 施工人员在工作中利用电源时, 出现了 违规操作的情况, 当施工人员需要离开 电源处进行施工时, 为了加快施工速度 就会出现私接电源的情况, 并且安全管 理人员也没有针对这一问题进行整顿, 长此以往就导致施工人员的生命安全受 到威胁, 同时也埋下了十分严重的安全 隐患。 


\section{3 加强水利工程安全管理的 措施}

3. 1加强安全生产自身建设

为了加强水利工程管理效率提高水 利工程安全, 相关施工单位应建立完善 的管理制度, 从而保证水利工程建设有 据可依, 降低水利工程施工事故发生率。 因此相关施工单位在工作过程中, 就要 在企业内部建立安全管理岗位, 并设立 专业的施工现场安全管理员, 专门监管 水利工程施工中的安全问题。同时企业 还要将管理权限下放, 将人员调度权利 分配给安全管理专员, 从而提高安全管 理人员声望, 保证安全管理人员的工作 可以有效开展 ${ }^{[3]}$ 。

\section{2加强安全生产宣传教育}

因为在水利工程建设过程中, 大部 分施工人员都是农民工并且专业能力 不足, 所以相关施工单位在提高工程管 理效率时, 就要重视对农民工专业能力 的培训。在施工人员作业时不断规范施 工方式, 管理人员还要提高对施工人员 的现场管理, 同时定期组织施工人员开 展安全教育讲座, 并在日常工程建设中 不断向施工人员传递安全观念, 保证施 工人员养成安全施工意识。不仅如此, 施工单位还要对特种作业人员进行更 加专业的培训, 并定期对特种作业人员 进行专业能力考试, 使特种作业人员可 以重视起特种作业, 正确对待自己的本 职工作, 以保证特种作业人员在施工过 程中, 可以提高安全意识增强特种专业 能力。

3. 3 从根源上深度排查安全隐患

一般情况下严重的水利工程安全事 故, 都是经过长时间的错误施工累计出 现的, 并且这些安全隐患还具有较强的 隐蔽性。因此在水利工程管理过程中, 相关施工单位就要重视这一问题, 在安
全管理过程中不要一味的管理表面, 要 通过更深层次的管理提高水利工程安全 性。首先, 相关施工单位的管理部门要提 高安全管理意识, 在工作中认真监管施 工单位的建设工作, 不断规范水利工程 安全管理工作。其次, 施工单位要提高安 全管理人员的专业能力, 保证安全管理 人员在工作中做到 “施工质量, 安全为 先, , 还要将安全管理工作所覆盖的管理 范围拓宽, 通过提高安全管理人员专业 能力, 保证水利工程整体质量, 同时为施 工人员的生命安全提供保障。与此同时, 安全管理人员在进行实际安全排查过程 中, 一定要严格管理施工人员的工作方 式, 坚决杜绝施工人员在工作过程中出 现违规操作的情况, 同时还要检查施工 人员的安全防护用具是否配备齐全, 劳 动保障用品是否按规定佩戴。通过从上 到下的严格管理, 提高水利工程施工安 全, 保证水利工程稳定建设, 保证施工人 员生命安全。

3. 4 加大管理力度做好安全隐患预 防工作

安全管理重在预防, 因此相关施工 单位在进行工程管理时, 一定要加大安 全隐患预防力度, 当发现施工现场出现 安全隐患时, 一定要及时对其进行整改, 若是遇到较难的安全隐患问题时, 要立 刻向有关部门进行汇报。若是在施工中 存在明知故犯、不知悔改、隐瞒不报的 情况, 就会造成更加严重的施工安全事 故, 所以相关安全管理人员在工作时, 要 做到时刻检查及时汇报, 加强安全隐患 预防工作, 避免安全隐患发展成安全事 故, 以保证水利工程安全。

3.5 建立科学合理的安全管理体系

“没有规矩, 不成方圆”, 在水利工 程管理过程中, 相关施工单位不仅要规 范管理人员的工作, 还要建立相对规范
的管理体系, 进而保证施工人员可以将 安全问题放在心上。施工单位可以建立 明确的奖惩措施, 并将安全问题与施工 人员绩效挂钩, 同时安全管理人员一定 要将惩罚措施落实, 从而加强施工人员 安全意识。与此同时, 施工单位还可以选 择树立一些模范员工, 并对其进行相应 的绩效奖励, 来激励施工人员养成安全 意识, 以提高水利工程安全性, 进而避免 出现严重生产安全问题, 推动水利工程 稳定建设 ${ }^{[4]}$ 。

\section{4 结束语}

水利工程是我国重要的发展设施, 同时也是地区经济发展以及群众稳定生 活的重要设施, 并且水利工程所包含的 建筑技术较多。因此, 在水利工程建设过 程中, 相关施工单位一定要重视水利工 程的管理方式, 在施工管理过程中万事 都要以安全为重, 管理人员还要加强施 工现场的安全管理, 以保证施工人员生 命安全, 提高水利工程建设效率, 高效完 成我国水利工程项目建设。相信在有关 部门的努力下, 我国水利工程施工质量 一定会得到提升, 并且施工中的安全问 题也会得到解决, 水利工程一定会为我 国带来更高的经济效益。

\section{[参考文献]}

[1]薛招钱.水利工程施工安全管理 措施探究[J].名城绘,2019,(5):529.

[2]刘兴春.水利工程施工安全 管理 问题探讨 [J]. 科技经济导 刊,2018,26(10):54-55.

[3]刘公海. 水利工程施工安全 管理缺陷及对策研究 [J]. 四川建 材,2019,45(4):225-226.

[4]刘珂,方茂茹,朱栅.浅谈水利 水电工程施工安全管理 [J]. 四川水 利,2018,39(1):93-95. 